\title{
Soil macrofauna under different land uses in the Colombian Amazon
}

\author{
Leonardo Rodríguez Suárez ${ }^{(1)}$, Yuli Tatiana Paladines Josa(1), Erika Judith Astudillo Samboni ${ }^{(1)}$, \\ Karla Dayana Lopez Cifuentes ${ }^{(1)}$, Ervin Humprey Durán Bautista(1) and Juan Carlos Suárez Salazar ${ }^{(1)}$
}

(1)Universidad de la Amazonia, Facultad de Ingeniería, Programa Ingeniería Agroecológica, Calle 17 Diagonal 17 con Carrera 3F, Código Postal 180002 Florencia, Colombia. E-mail: I.rodriguezsuarez@outlook.com, y.paladines@udlaedu.onmicrosoft.com, er.astudillo@udlaedu.onmicrosoft.com, karl.lopez@udlaedu.onmicrosoft.com, ervinduranb@gmail.com, juansuarez1@gmail.com

\begin{abstract}
The objective of this work was to evaluate the soil macrofauna and the bioindicator taxonomic groups associated with different land uses in the Colombian Amazon. Twelve agroforestry arrangements were studied and compared with to the native forest and pasture. For each land use, six monoliths were randomly selected and divided into four layers (litter, and 0-10, 10-20, and 20-30 cm soil depths). The variables considered in the analysis of land use effects were: individuals per square meter, order richness, Shannon's diversity index, and Pielou's evenness index. The greatest values for soil macrofauna density and diversity occurred in the forest, in contrast with the pasture. The principal component analysis distinguished land use according to macrofauna diversity, separating the native forest from the other land uses. The cluster analysis indicated the potential of some agroforestry systems to conserve the values of soil macrofauna density and diversity similar to those of the forest. According to the analysis of indicator value, five taxonomic groups (Diplura, Pseudoscorpionida, Araneae, Chilopoda, and Gastropoda), identified as bioindicators, are associated with preserved sites because of the sensitivity of their populations.
\end{abstract}

Index terms: agroforestry systems, bioindicators, richness, soil macrofauna.

\section{Macrofauna edáfica em diferentes usos da terra na Amazônia colombiana}

Resumo - O objetivo deste trabalho foi avaliar a macrofauna edáfica e os grupos taxonômicos bioindicadores associados a diferentes usos da terra na Amazônia colombiana. Doze arranjos agroflorestais foram estudados e comparados com a mata nativa e a pastagem. Para cada uso da terra, seis monólitos, divididos em quatro camadas (serrapilheira, e 0-10, 10-20 e 20-30 cm de profundidade) foram coletados aleatoriamente. As variáveis consideradas na análise do efeito dos usos da terra foram: indivíduos por metro quadrado, riqueza de ordens, índice de diversidade de Shannon e índice de equidade de Pielou. Os maiores valores de densidade e diversidade de macrofauna do solo ocorreram na floresta, em contraste com a pastagem. A análise dos componentes principais distinguiu os usos do solo de acordo com a diversidade da macrofauna, tendo separado a floresta nativa dos outros usos da terra. A análise de agrupamento indicou o potencial de alguns sistemas agroflorestais para conservar os valores de densidade e diversidade da macrofauna edáfica semelhantes aos da floresta. De acordo com a análise do valor do indicador, cinco grupos taxonômicos (Diplura, Pseudoscorpionida, Araneae, Chilopoda e Gastropoda), identificados como bioindicadores, estão associados a locais conservados, em razão da sensibilidade de suas populações.

Termos de indexação: sistemas agroflorestais, bioindicadores, riqueza, macrofauna do solo.

\section{Introduction}

Soil provides an ample variety of ecosystem services that benefits the human population, and allows of ecosystems to adequately function (Wall et al., 2012). Moreover, it is considered a large reservoir of biodiversity, as macrofauna is an important component of soil biological diversity (Blouin et al., 2013).

Soil macrofauna plays an important role in the regulation of ecosystem functions (Marichal et al., 2014; Lavelle et al., 2016) because they contribute to controlling Creative Commons Attribution 4.0 International License soil structure (Bottinelli et al., 2015), modifying the soil aggregation and porosity (Velásquez et al., 2012), consequently improving infiltration and changing water retention patterns (Lavelle et al., 2014). In addition, they contribute to the organic matter mineralization and litter decomposition (Frouz et al., 2015).

Macrofauna can be used as a biological indicator of the impacts on land use, for its relationship with the physical and chemical properties of the soil, and for its rapid variation over a short period of time that is a product of changes in cover and transformation in vegetation (Rousseau et al., 2013).

Pesq. agropec. bras., Brasília, v.53, n.12, p.1383-1391, Dec. 2018 DOI: 10.1590/S0100-204X2018001200011 
To that effect, many studies have developed initiatives to identify bioindicator taxons associated with a particular habitat or land use conditions, as well as to associate bioindicator taxons with ecosystem functions and services of the soil (Rousseau et al., 2013; Vasconcellos et al., 2013; Lavelle et al., 2014; Marichal et al., 2014). Despite these initiatives, the deforestation and conversion of Amazon forests into pastures and crop lands can have profound effects on soil biodiversity and, consequently, impact the soil functions, the dynamics of its organic matter, the soil nutrient cycle, and soil physical characteristics such as bulk density, porosity, and water availability (Velásquez et al., 2012; Lavelle et al., 2016).

In this scenario, agroforestry systems are land uses that can exhibit great similarities to natural forests due to their forest cover and litter (Baretta et al., 2011; Oliveira et al., 2018). Practices associated with agroforestry systems such as the inclusion of vegetation that is structurally and taxonomically diverse, as well as the presence of a continuous soil cover, seem to be associated with the abundance and diversity of soil macrofauna (Moço et al., 2010; Pauli et al., 2011; Kamau et al., 2017).

The objective of this work was to evaluate the soil macrofauna and bioindicator taxonomic groups associated with different land uses in the Colombian Amazon.

\section{Materials and Methods}

This study was carried out between March and May of 2016, at the Macagual Center for Amazonian Research - Cesar Augusto Estrada Gonzalez, located in the western Colombian Amazon $\left(1^{\circ} 30^{\prime} 4.87^{\prime \prime} \mathrm{N}\right.$ and $\left.75^{\circ} 39^{\prime} 47.16^{\prime \prime} \mathrm{W}\right)$. This center is in a humid area with an annual average precipitation of $3,793 \mathrm{~mm}$, a monomodal rainfall regime with maximum precipitation distributed between April and September, 1,707 hours of sunshine per year, $25.5^{\circ} \mathrm{C}$ average temperature, and $84.3 \%$ relative humidity. Soil macrofauna was collected from 14 land uses, 12 agroforestry arrangements contrasted with native forest (positive control), and pasture (negative control) (Table 1).

In order to quantify the macrofauna, the ISO 23611-5 standard was used (ISO, 2011). Six monoliths were randomly collected from each land use (blocks of $25 \times 25 \mathrm{~cm}$ and $30 \mathrm{~cm}$ deep). Each monolith was separated into four layers: litter, and 0-10, 10-20, 20-30 $\mathrm{cm}$ depths. The soil was inspected manually in situ. Existing soil macrofauna was then preserved in $70 \%$ alcohol, separated in the lab according to morphology, and identified into class or order.

Variables considered in the analysis for land use impact were: individuals per $\mathrm{m}^{2}$, order richness, Shannon's diversity index $(\mathrm{H})$, and Pielou's evenness index (e). Soil macrofauna data were normalized using $\log (\mathrm{x}+1)$, and were compared using Fisher's LSD test, at $5 \%$ probability. Due to the low density in some taxonomic groups $(<0.2 \%$ of total density), these were grouped into the "others" category (Dermaptera, Lepidoptera, Mantodea, Nematodo, Neuroptera, Opiliones, Orthoptera, Phasmida, Psocoptera, and Scorpion); however, each group was considered when calculating richness and diversity indices. A completely random design was applied to subdivided plots using six monoliths per land use as replicates. The principal plot was land use, and the subplot was each depth, according to the model $\mathrm{Y}_{\mathrm{ijk}}=\mu+\mathrm{Us}_{\mathrm{i}}+\varepsilon_{\mathrm{i}}$ $+\mathrm{P}_{\mathrm{j}}+\mathrm{UsP}_{\mathrm{ij}}+\varepsilon \mathrm{k}_{(\mathrm{ij})}$, in which: $\mathrm{Y}_{\mathrm{ijk}}$ is the observation; $\mu$ is the mean; $U_{s i}$ is the effect of the $i^{\text {th }}$ land use; $\varepsilon_{i}$ is the error due to land use; $\mathrm{H}_{\mathrm{j}}$ is the effect of the $\mathrm{j}^{\text {th }}$ depth; $\mathrm{UsP}_{\mathrm{ij}}$ is the interaction land use $\mathrm{x}$ depth; and $\varepsilon \mathrm{k}_{(\mathrm{ij})}$ is the error due to depth.

In order to determine similarities between land uses, and to explore the relationship between macrofauna groups, a principal component analysis (PCA) was conducted. The impact of different land uses was tested using the Monte-Carlo test. Subsequently, land uses were grouped into a similarity dendrogram according to data on macrofauna density and richness, using the Ward's method and the Euclidian distance. The optimal number of clusters was determined considering 26 cluster validation indexes (Charrad et al., 2014).

The bioindicator taxonomic groups associated with different land uses were determined using the indicator value (IndVal), a method that indicates the strength and significance of the association between a taxon and a previously defined group (that is, habitats), ranging from 0 (no association) to 1 (maximum association) (Dufrêne \& Legendre, 1997). Significance was measured using a randomization procedure (MonteCarlo test, 1,000 simulations) and the Holm-Bonferroni correction for multiple tests. Taxons exhibiting IndVal values above 0.7 , therefore significant, are considered characteristic or indicative of a habitat; taxons with values under 0.7 are considered detectors of ecological change (McGeoch et al., 2002).

All multivariate analyses were carried out using the software $\mathrm{R}$ version 3.4.3 (R Core Team, 2017). The ade4 
Table 1. Description of the land uses studied at the Macagual Center for Amazonian Research - Cesar Augusto Estrada Gonzalez, located in the western Colombian Amazon.

\begin{tabular}{|c|c|}
\hline Land uses & Description \\
\hline Native forest (NF) & Natural system of approximately 40 years without any type of human intervention. \\
\hline $\begin{array}{l}\text { Shade trees for cultivation } \\
\text { (STC) }\end{array}$ & $\begin{array}{l}\text { Agroforestry system established for } 24 \text { years, which combines the trees paricá (Schizolobium amazonicum Huber ex Ducke), } \\
\text { rubber [Hevea brasiliensis (Willd. ex A. Juss.) Müll. Arg.], and peach palm (Bactris gasipaes Kunth) with the fruit tree } \\
\text { copoazú [Theobroma grandiflorum (Willd. ex Spreng.) K.Schum.]. }\end{array}$ \\
\hline Improved fallow (IF) & $\begin{array}{l}\text { Agroforestry system established for } 20 \text { years, composed of species that naturally regenerate such as peine mono [Apeiba } \\
\text { membranacea (Spruce ex Benth.)], snakewood (Cecropia peltata L.), boca de indio [Piptocoma discolor (Humb., Bonpl. \& } \\
\text { Kunth) Pruski], and tachuelo (Lacmellea edulis H. Karst); enriched with peach palm (Bactris gasipaes Kunth), ice cream } \\
\text { bean (Inga edulis Mart.), arazá (Eugenia stipitata McVaugh), copoazú [Theobroma grandiflorum (Willd. ex Spreng.) K. } \\
\text { Schum.] and pataxte (Theobroma bicolor Humb. \& Bonpl.). }\end{array}$ \\
\hline Cropping in alleys 1 (CA1) & $\begin{array}{l}\text { Agroforestry system implemented for } 20 \text { years, in which timber tree seed were sown in rows, with a predominance of the } \\
\text { species Amazon tree-grape (Pourouma cecropiifolia Mart.), associated with cedro (Cedrela odorata L.), higuerón (Ficus } \\
\text { luschnathiana Miq.), boca de indio [Piptocoma discolor (Humb., Bonpl. \& Kunth) Pruski], white chilco (Miconia appen- } \\
\text { diculata Triana), laurel (Laurus nobilis L.), gamhar (Gmelina arborea Roxb ex Sm.), ice cream bean (Inga edulis Mart.), } \\
\text { guacharaco (Cupania cinerea Poepp. \& Endl.) and lacre (Vismia angosta); between the rows are arazá (Eugenia stipitata } \\
\text { McVaugh) and copoazú [Theobroma grandiflorum (Willd. ex Spreng.) K.Schum.]. The system is geogaphically located near } \\
\text { water bodies. }\end{array}$ \\
\hline Cropping in alleys 2 (CA2) & $\begin{array}{l}\text { Agroforestry system established for } 25 \text { years, in which the tree seed were sown in rows with a predominance of the species } \\
\text { peach palm (Bactris gasipaes Kunth) and rubber [Hevea brasiliensis (Willd. ex A. Juss.) Müll. Arg.], achapo [Cedrelinga } \\
\text { cateniformis (Ducke) Ducke] is found at a low density, yarumo (Cecropia peltata L.), and ice cream bean (Inga edulis } \\
\text { Mart.); between the rows are cacao (Theobroma cacao L.), arazá (Eugenia stipitata McVaugh) and copoazú [Theobroma } \\
\text { grandiflorum (Willd. ex Spreng.) K.Schum.]. }\end{array}$ \\
\hline $\begin{array}{l}\text { Cropping in forest } \\
\text { plantation } 1 \text { (CFP1) }\end{array}$ & $\begin{array}{l}\text { Agroforestry system established for } 24 \text { years, with a predominance of a type of rubber tree ([Hevea brasiliensis (Willd. ex A. } \\
\text { Juss.) Müll. Arg.] characterized by its broad leaves, associated with the fruit trees copoazú [Theobroma grandiflorum (Willd. } \\
\text { ex Spreng.) K.Schum.] and arazá (Eugenia stipitata McVaugh). }\end{array}$ \\
\hline $\begin{array}{l}\text { Cropping in forest } \\
\text { plantation } 2 \text { (CFP2) }\end{array}$ & $\begin{array}{l}\text { Agroforestry system established for } 24 \text { years, with a predominance of a type of rubber tree [Hevea brasiliensis (Willd. ex } \\
\text { A. Juss.) Müll. Arg.] characterized by its small leaves, associated with the fruit trees arazá (Eugenia stipitata McVaugh) and } \\
\text { copoazú [Theobroma grandiflorum (Willd. ex Spreng.) K.Schum.]. Because the canopy of the system allows of a constant } \\
\text { radiation to enter, pioneer vegetation develops and, consequently, clearing activities and the use of herbicides are performed } \\
\text { within the system at least twice a year. }\end{array}$ \\
\hline $\begin{array}{l}\text { Cropping in forest } \\
\text { plantation } 3 \text { (CFP3) }\end{array}$ & $\begin{array}{l}\text { Agroforestry system implemented for } 21 \text { years, composed of the species huito (Genipa Americana L.), bilibil [Guarea gui- } \\
\text { donia (L.) Sleumer], higuerón (Ficus luschnathiana Miq.), wild cashew [Anacardium excelsum (Kunth) Skeels], Honduran } \\
\text { mahogany (Swietenia macrophylla King.), laurel [Cordia alliodora (Ruiz \& Pav.) Oken)], tachuelo (Lacmellea edulis H. } \\
\text { Karst), Juan soco (Couma macrocarpa Barb.Rodr.), and sangre toro [Virola elongata (Benth.) Warb], associated with the } \\
\text { fruit trees copoazú [Theobroma grandiflorum (Willd. ex Spreng.) K.Schum.], arazá (Eugenia stipitata McVaugh), and plan- } \\
\text { tain (Musa paradisiaca L.). The system is geogaphically located near water bodies. Some areas of the system experience } \\
\text { floods during periods of maximum precipitation. }\end{array}$ \\
\hline $\begin{array}{l}\text { Home garden } \\
\text { (HG) }\end{array}$ & $\begin{array}{l}\text { Agroforestry system implemented for } 26 \text { years that combines diverse fruit trees such as copoazú [Theobroma grandiflo- } \\
\text { rum (Willd. ex Spreng.) K.Schum.], pataxte (Theobroma bicolor Bonpl.), custard apple (Annona cherimola Miller), borojó } \\
\text { (Borojoa patinoi Cuatrec.), cacao (Theobroma cacao L.), mango (Mangifera indica L.), and peach palm (Bactris gasipaes } \\
\text { Kunth); Colombian mahogany (Cariniana pyriformis Miers), wild cashew [Anacardium excelsum (Kunth) Skeels], chingale } \\
\text { [Jacaranda copaia (Aubl.) D.Don.], and capirona (Capirona decorticans Spruce) are found in low densities. }\end{array}$ \\
\hline Forest plantation 1 (FP1) & $\begin{array}{l}\text { Agroforestry system implemented for } 18 \text { years, and characterized by a predominance of the species Colombian mahogany } \\
\text { (Cariniana pyriformis Miers), and some species found at low densities such as cedro (Cedrela odorata L.), Honduran } \\
\text { mahogany (Swietenia macrophylla King), carbon (Zygia longifolia [Humb. \& Bonpl. ex Willd.) Britton \& Rose], bilibil } \\
\text { [Guarea guidonia (L.) Sleumer], saman [Samanea saman (Jacq.) Merr.], pink trumpet tree [Tabebuia rosea (Bertol.) DC.], } \\
\text { higuerón (Ficus luschnathiana Miq.), and arazá (Eugenia stipitata McVaugh). The system is geographically located near } \\
\text { water bodies. Some areas of the system experience floods during periods of maximum precipitation. }\end{array}$ \\
\hline Forest plantation 2 (FP2) & $\begin{array}{l}\text { Agroforestry system implemented for } 18 \text { years, characterized by a predominance of the species black manwood (Minquartia } \\
\text { guianensis Aubl.), associated with arazá (Eugenia stipitata McVaugh) and the Amazon tree-grape (Pourouma cecropiifolia } \\
\text { Mart.). The system is geogaphically located near water bodies. }\end{array}$ \\
\hline Natural regeneration (NR) & $\begin{array}{l}\text { Natural regeneration of } 15 \text { years, composed of the species Amazon tree-grape (Pourouma cecropiifolia Mart.), cedro (Cedre- } \\
\text { la odorata L.), laurel (Laurus nobilis), ice cream bean (Inga edulis Mart.), white chilco (Miconia appendiculata Triana), bla- } \\
\text { ck chilco (Miconia elata (Sw.) DC.), yarumo (Cecropia peltata L.), and achapo [Cedrelinga cateniformis (Ducke) Ducke]. }\end{array}$ \\
\hline Silvipastoral system (SSP) & $\begin{array}{l}\text { Silvipastoral system established for } 13 \text { years, in which the shade trees gamhar (Gmelina arborea Roxb ex Sm.), carbon } \\
\text { [Zygia longifolia [Humb. \& Bonpl. ex Willd.) Britton \& Rose], boca de indio [Piptocoma discolor (Humb., Bonpl. \& Kunth) } \\
\text { Pruski], and guayabo coronillo (Bellucia pentamera Naudin) were incorporated in pastures in a circular area of } 100 \mathrm{~m} \text { diam- } \\
\text { eter. Animals seeking shade and a place to rest frequently concentrate under the tree canopy. }\end{array}$ \\
\hline Pasture (PA) & Conventional system composed of the grasses Urochloa decumbens and Urochloa humidicola. \\
\hline
\end{tabular}


package was used for the PCA and the Monte-Carlo test (Dray et al., 2007), the factoextra and NbClust packages were used for cluster development (Charrad et al., 2014), and the labdsv package for IndVal.

\section{Results and Discussion}

The total number of registered individuals was 7,854 , from which Isoptera and Hymenoptera were the most abundant (2,937 and 2,241 individuals). Average density per soil sample was $1,496 \pm 155$ individuals per $\mathrm{m}^{2}$. Twenty-five taxonomic groups were identified, with an average richness per soil sample of $7.8 \pm 0.29$ taxons. Significant differences were found between land uses $(\mathrm{p}<0.05)$; native forest (NF) was different from the rest for total density and richness (Figure 1).

These results indicate that a higher-tree diversity can result in greater heterogeneity and quantity of litter and, consequently, a greater supply of food and microhabitats, as well as better soil conditions and favorable microclimate for macrofauna (Rosa et al., 2015; Korboulewsky et al., 2016). On this subject, Gibson et al. (2011) indicates that there is no substitute for the forest, when it comes to preserving tropical biodiversity.

From the collected soil macrofauna, $78 \%$ was found in the first two soil layers, $43 \%$ of which was found in the litter, and $35 \%$ at $0-10 \mathrm{~cm}$ soil depth. This tendency was likewise true for each land use (Figure 2), with depth affecting the distribution of macrofauna
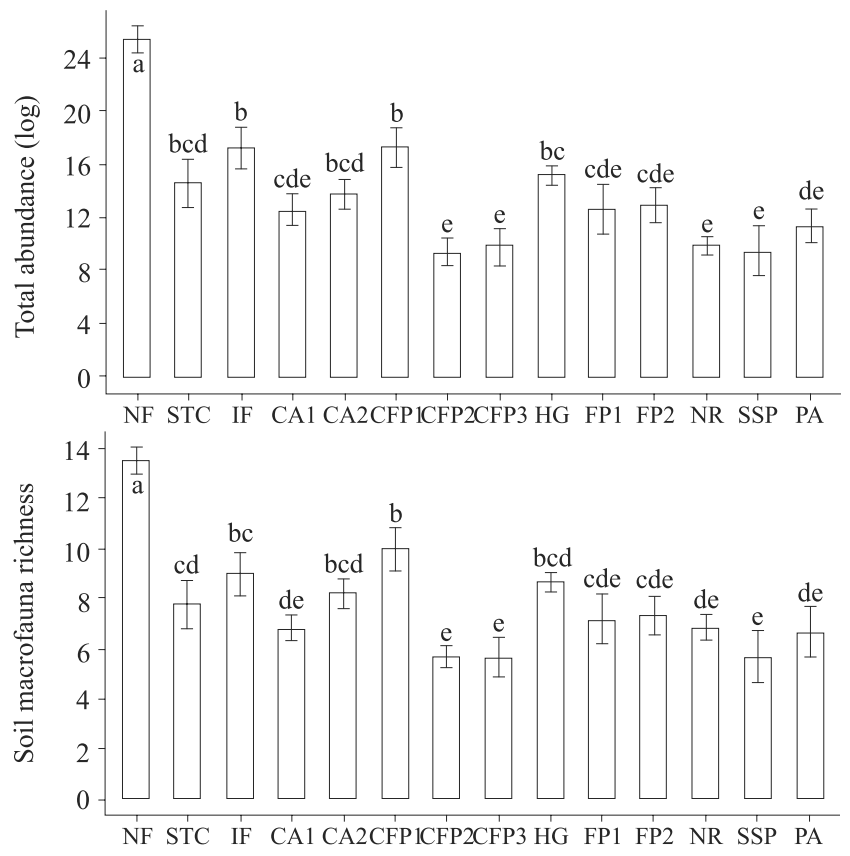

Figure 1. Total density $(\log )$ and richness of soil macrofauna in each land use: native forest (NF), shade trees for cultivation (STC), improved fallow (IF), cropping in alleys 1 (CA1), cropping in alleys 2 (CA2), cropping in forest plantation 1 (CFP1), cropping in forest plantation 2 (CFP2), cropping in forest plantation 3 (CFP3), home garden (HG), forest plantation 1 (FP1), forest plantation 2 (FP2), natural regeneration (NR), silvipastoral system (SSP), and pasture (PA), in the Colombian Amazon. Different letters indicate different levels of significance, by the LSD Fisher test, at $5 \%$ probability; and error bars represent standard error.

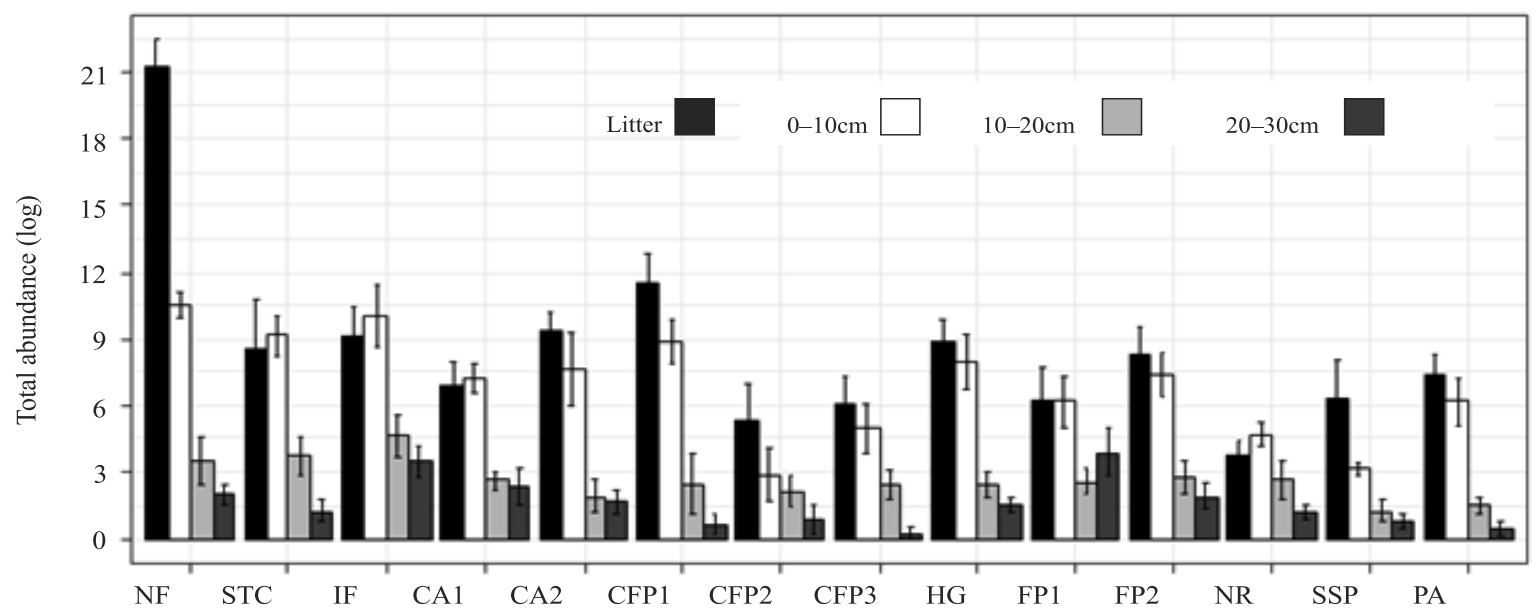

Figure 2. Total density (log) of soil macrofauna divided by soil layer, in each land use: native forest (NF), shade trees for cultivation (STC), improved fallow (IF), cropping in alleys 1 (CA1), cropping in alleys 2 (CA2), cropping in forest plantation 1 (CFP1), cropping in forest plantation 2 (CFP2), cropping in forest plantation 3 (CFP3), home garden (HG), forest plantation 1 (FP1), forest plantation 2 (FP2), natural regeneration (NR), silvipastoral system (SSP), and pasture (PA), in the Colombian Amazon. Error bars represent standard error. 
(Santos et al., 2016). This is possibly due to a decrease of oxygen content, soil organic matter, and root biomass as the soil profile deepens (Pauli et al., 2011). However, NF was significantly different from the other land uses, exhibiting the highest density of soil macrofauna in litter (Figure 2), which coincides with the statements of Negrete-Yankelevich et al. (2007), claiming that soil macrofauna in preserved forests is primarily found in litter, whereas they are more abundant in the soil of disturbed areas.

As to the ecological indexes, while the highestShannon's diversity (H) and Pielou's evenness (e) values were found in the use of land with natural regeneration (NR), there were no stark differences between this and other land uses (Figure 3). According to Barros et al. (2008), an absence of clear dominance between groups of macrofauna occurs when organic matter input is diversified, which allows of the colonization

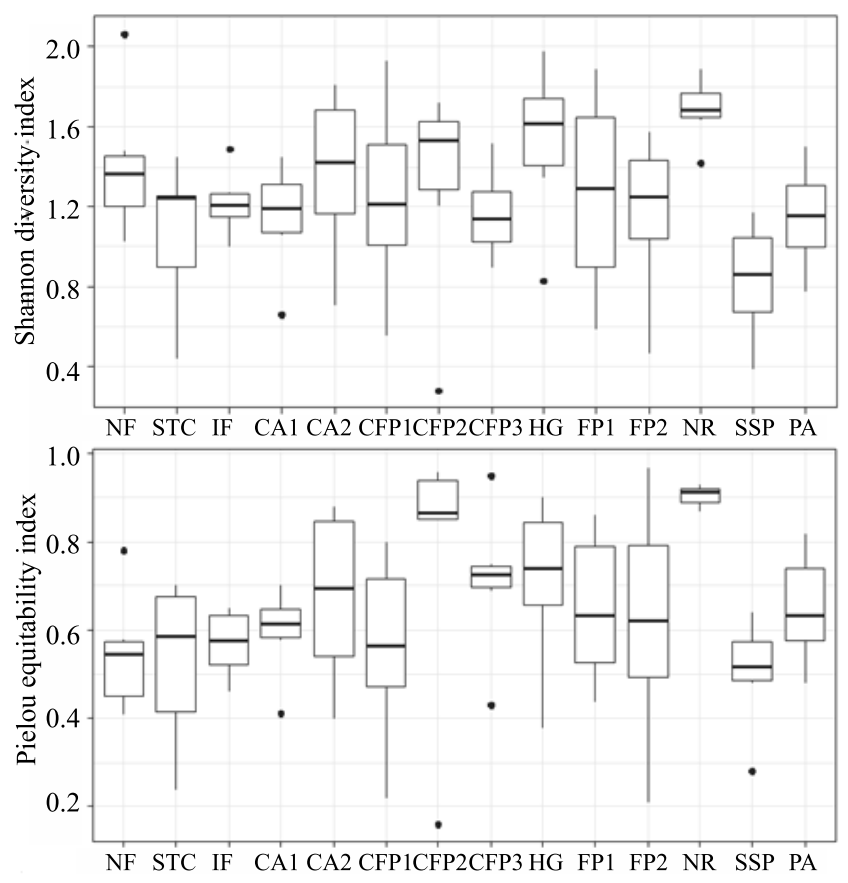

Figure 3. Box plot of Shannon's diversity index and Pielou's evenness index for each land use: native forest (NF), shade trees for cultivation (STC), improved fallow (IF), cropping in alleys 1 (CA1), cropping in alleys 2 (CA2), cropping in forest plantation 1 (CFP1), cropping in forest plantation 2 (CFP2), cropping in forest plantation 3 (CFP3), home garden (HG), forest plantation 1 (FP1), forest plantation 2 (FP2), natural regeneration (NR), silvipastoral system (SSP), and pasture (PA), in the Colombian Amazon. of different organisms; this fact relates to NR, which is the use of a young land in the process of recovery.

Although NF exhibited greater richness, the predominance of the Isoptera group in this land use affected evenness in other groups, causing the forest to exhibit low values on the ecological indexes. Similar results were reported by Lima et al. (2010) who, when evaluating the abundance and diversity of macroinvertebrates in different agroecosystems, recorded the lowest values of the diversity and evenness indexes for native forests; this was attributed to the dominance of the Isoptera group. Therefore, a better representation of diversity can be expected when it is measured using the taxonomic richness (Pereira et al., 2017).

The PCA showed that the first two axes explained $37.2 \%$ of the total variability in the data (Figure 4). Axis 1 showed a gradient of macrofauna diversity from left to right, clearly isolating NF as the land use with the greatest soil macrofauna diversity (Figure 4 A). Axis 2 related those land uses with the highest density of Isopoda and Gastropoda, in which the closest one was the improved fallow. According to the MonteCarlo test, the differences between macrofauna groups in different land uses were significant (46\% explained variance, $\mathrm{p}<0.001$ ).

Some systems, such as silvipastoral system (SSP), cropping in forest plantation 3 (CFP3), and cropping in forest plantation 2 (CFP2), did not exhibit any relationship with macrofauna in the respective factorial plane (F1/F2) of the PCA (Figure 4 B). The SSP, which includes shade trees in pasture, had an indirect impact on macrofauna, possibly due to excessive the trampling of animals searching for shade and a place to rest (Morales-Márquez et al., 2018). The CFP3 system, characterized by seasonal or periodic floods, may have affected macrofauna. According to Coyle et al. (2017), increases of flood frequency and duration generally lead to a decrease of the abundance of soil macrofauna; this is due to periods of hypoxia or anoxia caused by fluctuations of soil humidity levels. In the case of CFP2, lowcanopy cover possibly affected macrofauna as reported by Amazonas et al. (2018), who found a positive correlation between canopy cover and macrofauna density (Pearson, $\mathrm{p}=0.017, \mathrm{r}=0.43$ ); this effect occurred in addition to the intense use caused

Pesq. agropec. bras., Brasília, v.53, n.12, p.1383-1391, Dec. 2018 DOI: $10.1590 / \mathrm{S} 0100-204 \mathrm{X} 2018001200011$ 

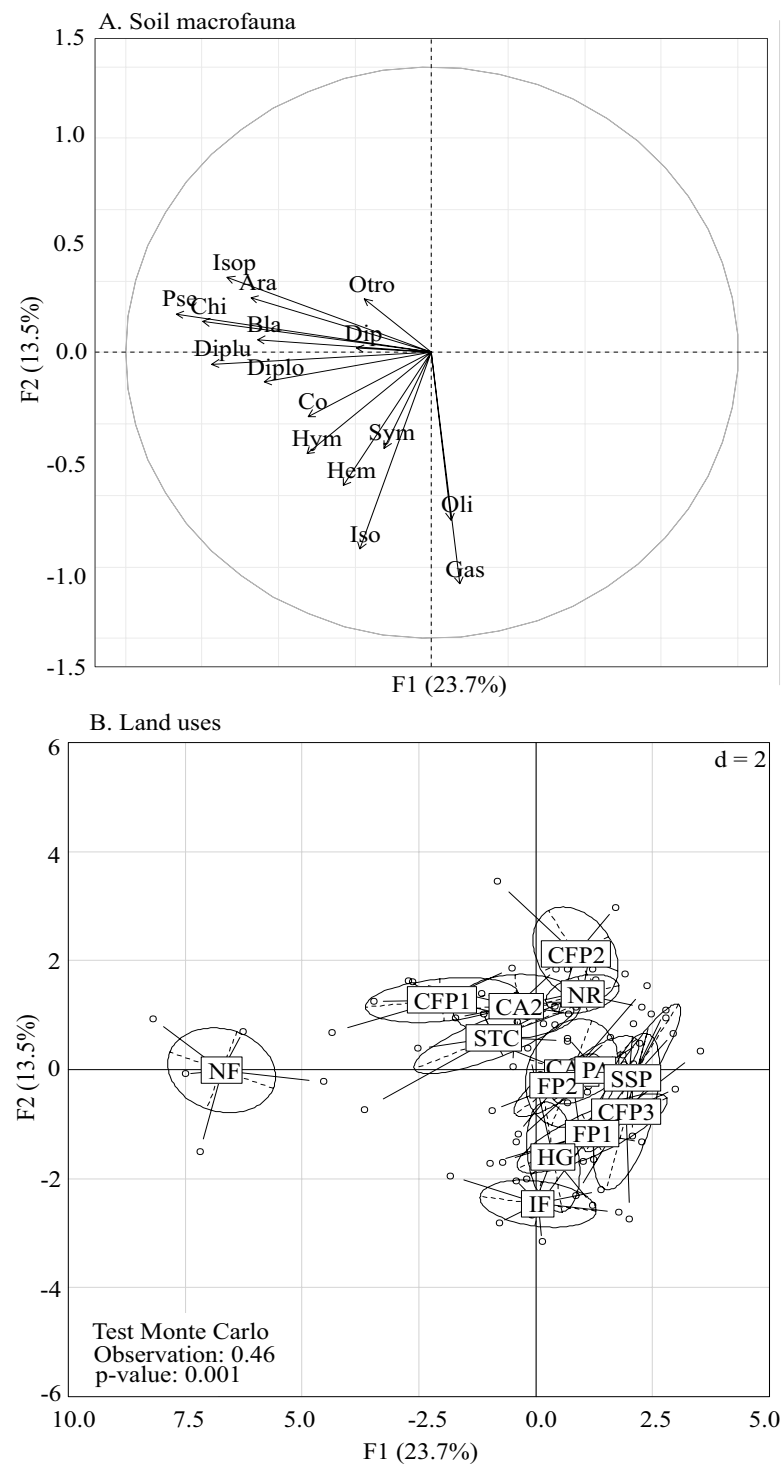

Figure 4. Projection on the factorial plane F1/F2 of a principal component analysis of the variables of soil macrofauna and sample points grouped according to land use. A, circle of correlation between groups of the following soil macrofauna: Araneae (Ara), Blattodea (Bla), Coleoptera (Col), Chilopoda (Chi), Diplopoda (Diplo), Diptera (Dip), Diplura (Diplu), Gastropoda (Gas), Hymenoptera (Hym), Hemiptera (Hem), Isopoda (Iso), Isoptera (Isop), Oligochaeta (Oli), Pseudoscorpionida (Pse), Symphyla (Sym), and others (other). B, sample arrangement for land use: native forest (NF), shade trees for cultivation (STC), improved fallow (IF), cropping in alleys 1 (CA1), cropping in alleys 2 (CA2), cropping in forest plantation 1 (CFP1), cropping in forest plantation 2 (CFP2), cropping in forest plantation 3 (CFP3), home garden (HG), forest plantation 1 (FP1), forest plantation 2 (FP2), natural regeneration (NR), silvipastoral system (SSP), and pasture (PA), in the Colombian Amazon. by clearing and herbicide applications (Scoriza et al., 2015).

The cluster analysis grouped three optimal groups according to their capacity to preserve the density and diversity of macrofauna (Figure 5). In the first cluster, NF was the land use that allowed of the greatest preservation of macrofauna. The second cluster was composed of the agroforestry systems home garden (HG), shade trees for cultivation (STC), cropping in alleys 2 (CA2), improved fallow (IF), and cropping in forest plantation 1 (CFP1), indicating that a diversification of vegetal species, a continuous deposit of vegetal residue, and soil without tillage provide a favorable environment for macrofauna diversity (Moço et al., 2010) that, in our study, showed a similar degree of diversity to that of the forest. The remaining eight land uses concentrated in the third cluster, which included pasture (PA), NR, and the other agroforestry systems. It has been proven that the age of the system (Camara et al., 2018), variations in the microclimate caused by absence of a compact canopy (Kamau et al., 2017), the quantity and quality of litter (Oliveira et al., 2018), agricultural practices (Marichal et al., 2014), the use of herbicides (Scoriza et al., 2015), and animal trampling (Morales -Márquez et al., 2018) influence the soil macrofauna. Therefore, we suggest that the unfavorable presence of any of these factors, or

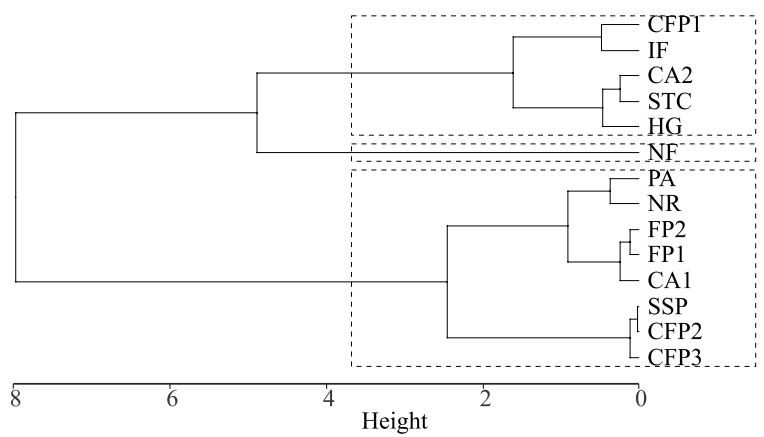

Figure 5. Cluster dendrogram for density and diversity of soil macrofauna in each land use: native forest (NF), shade trees for cultivation (STC), improved fallow (IF), cropping in alleys 1 (CA1), cropping in alleys 2 (CA2), cropping in forest plantation 1 (CFP1), cropping in forest plantation 2 (CFP2), cropping in forest plantation 3 (CFP3), home garden (HG), forest plantation 1 (FP1), forest plantation 2 (FP2), natural regeneration (NR), silvipastoral system (SSP), and pasture (PA), in the Colombian Amazon. 
their combination, in land uses, implied the obtention of average values of macrofauna and their respective grouping in the third cluster.

According to IndVal, five taxonomic groups exhibited significant values (Table 2). The Diplura group was identified as a habitat indicator associated with NF, reflecting the dependence of this group on places with low levels of disturbance. According to Baretta et al. (2011), they reside in humid places, moss, rocks, and litter within the forest. Meanwhile, Socarrás (2013) mentions that due to their morphologic characteristics and trophic role they are considered indicators of stability within soil.

The predators Pseudoscorpionida and Araneae were associated with NF and categorized as detectors of change (Table 2), which coincides with Vasconcellos et al. (2013) who affirm that these individuals are more abundant within natural systems, or in areas at a high level of conservation. The Chilopoda group, a detector of change, was associated with NF. This coincides with Marichal et al. (2014), who state that the density of chilopods is mainly associated with abundance in litter in wooded areas, and with a decreased number with deforestation. Thus, the relationship between forest

Table 2. Indicator value (IndVal) of the macrofauna groups, in different land uses, in the Colombian Amazon.

\begin{tabular}{lccc}
\hline Macrofauna & Land uses $^{(1)}$ & IndVal & p-valor \\
\hline Araneae & $\mathrm{NF}$ & 0.33 & $0.003^{* *}$ \\
Blattodea & $\mathrm{NF}$ & 0.34 & $0.110^{\text {ns }}$ \\
Chilopoda & $\mathrm{NF}$ & 0.39 & $0.005^{* *}$ \\
Coleoptera & $\mathrm{PA}$ & 0.15 & $0.943^{\text {ns }}$ \\
Diptera & $\mathrm{CA} 1$ & 0.08 & $1.000^{\text {ns }}$ \\
Diplopoda & $\mathrm{NF}$ & 0.29 & $0.052^{\text {ns }}$ \\
Diplura & $\mathrm{NF}$ & 0.73 & $0.003^{* *}$ \\
Gastropoda & $\mathrm{IF}$ & 0.33 & $0.022^{*}$ \\
Hemiptera & $\mathrm{CFP} 3$ & 0.16 & $1.000^{\mathrm{ns}}$ \\
Hymenoptera & $\mathrm{IF}$ & 0.25 & $0.150^{\text {ns }}$ \\
Isopoda & $\mathrm{IF}$ & 0.24 & $0.150^{\text {ns }}$ \\
Isoptera & $\mathrm{NF}$ & 0.29 & $0.117^{\text {ns }}$ \\
Oligochaeta & $\mathrm{CFP} 3$ & 0.17 & $0.091^{\text {ns }}$ \\
Pseudoscorpionida & $\mathrm{NF}$ & 0.68 & $0.003^{* *}$ \\
Symphyla & $\mathrm{PA}$ & 0.34 & $0.076^{\text {ns }}$ \\
\hline
\end{tabular}

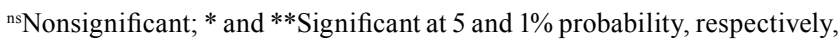
by the Monte-Carlo test. ${ }^{(1)}$ native forest (NF), pasture (PA), cropping in alleys 1 (CA1), improved fallow (IF), and cropping in forest plantation 3 (CFP3) and predators indicates a greater structural complexity in vegetation that, in turn, allows of the development of more complexity of trophic structure (Amazonas et al., 2018).

Finally, the taxon Gastropoda was associated with IF and categorized as a detector of change (Table 2). To that effect, Gerlach et al. (2013) mention that this group possesses a low dispersal capacity and will therefore reflect local conditions but not colonization. Consequently, gastropods can be good indicators of the quality of a habitat but not of the first stages of recovery.

The high capacity of the forest for preserving macrofauna diversity was reaffirmed by the IndVal, which provided four taxonomic groups that were significant for this land use. To obtain groups that are indicators means that they are the primary individuals at risk of disappearing as a result of habitat degradation. Meanwhile, groups that are detectors offer valuable information for monitoring the change across time, and can indicate which systems or land uses tend to stimulate macrofauna typical of forests (McGeoch et al., 2002).

\section{Conclusions}

1. Land uses affect soil macrofauna; their density and diversity vary with the intensity of land use and land management practices.

2. The agroforestry systems home garden (HG), shade trees for cultivation (STC), cropping in alleys 2 (CA2), improved fallow (IF), and cropping in forest plantation 1 CFP1 - can potentially preserve the density and diversity of soil macrofauna similar to that of the forest.

3. The Diplura, Pseudoscorpionida, Araneae, Chilopoda, and Gastropoda taxons are associated with preserved sites; the sensitivity of these groups to management practices allows their populations to serve as bioindicators.

\section{References}

AMAZONAS, N.T.; VIANI, R.A.G.; REGO, M.G.A.; CAMARGO, F.F.; FUJIHARA, R.T.; VALSECHI, O.A. Soil macrofauna density and diversity across a chronosequence of tropical forest restoration in Southeastern Brazil. Brazilian Journal of Biology, v.78, p.449-456, 2018. DOI: 10.1590/15196984.169014.

Pesq. agropec. bras., Brasília, v.53, n.12, p.1383-1391, Dec. 2018 DOI: 10.1590/S0100-204X2018001200011 
BARETTA, D.; SANTOS, J.C.P.; SEGAT, J.C.; GEREMIA, E.V.; OLIVEIRA FILHO, L.C.I. de; ALVES, M.V. Fauna edáfica e qualidade do solo. In: KLAUBERG FILHO, O.; MAFRA, A.L.; GATIBONI, L.C. (Ed.). Tópicos especiais em ciência do solo. Viçosa: Sociedade Brasileira de Ciência do Solo, 2011. p.119-170.

BARROS, E.; MAHIEU, J.; TAPIA-CORAL, S.; NASCIMENTO, A.R.L.; LAVELLE, P. Comunidade da macrofauna do solo na Amazônia brasileira. In: MOREIRA, F.M.S.; SIQUEIRA, J.O.; BRUSSAARD, L. (Ed.). Biodiversidade do solo em ecossistemas brasileiros. Lavras: UFLA, 2008. p.171-191.

BLOUIN, M.; HODSON, M.E.; DELGADO, E.A.; BAKER, G.; BRUSSAARD, L.; BUTT, K.R.; DAI, J.; DENDOOVEN, L.; PERES, G.; TONDOH, J.E.; CLUZEAU, D.; BRUN, J.-J. A review of earthworm impact on soil function and ecosystem services. European Journal of Soil Science, v.64, p.161-182, 2013. DOI: $10.1111 /$ ejss.12025.

BOTTINELLI, N.; JOUQUET, P.; CAPOWIEZ, Y.; PODWOJEWSKI, P.; GRIMALDI, M.; PENG, X. Why is the influence of soil macrofauna on soil structure only considered by soil ecologists? Soil and Tillage Research, v.146, p.118-124, 2015. DOI: 10.1016/j.still.2014.01.007.

CAMARA, R.; SANTOS, G.L. dos; PEREIRA, M.G.; SILVA, C.F. da; SILVA, V.F.V.; SILVA, R.M. Effects of natural Atlantic Forest regeneration on soil fauna, Brazil. Floresta e Ambiente, v.25, e20160017, 2018. DOI: 10.1590/2179-8087.001716.

CHARRAD, M.; GHAZZALI, N.; BOITEAU, V.; NIKNAFS, A. NbClust: an $\mathrm{R}$ package for determining the relevant number of clusters in a data set. Journal of Statistical Software, v.61, p.136, 2014. DOI: 10.18637/jss.v061.i06.

COYLE, D.R.; NAGENDRA, U.J.; TAYLOR, M.K.; CAMPBELL, J.H.; CUNARD, C.E.; JOSLIN, A.H.; MUNDEPI, A.; PHILLIPS, C.A.; CALLAHAM JR, M.A. Soil fauna responses to natural disturbances, invasive species, and global climate change: Current state of the science and a call to action. Soil Biology and Biochemistry, v.110, p.116-133, 2017. DOI: 10.1016/j. soilbio.2017.03.008.

DRAY, S.; DUFOUR, A.B.; CHESSEL, D. The ade4 package-II: Two-table and K-table methods. R News, v.7, p.47-52, 2007.

DUFRÊNE, M.; LEGENDRE, P. Species assemblages and indicator species: the need for a flexible asymmetrical approach. Ecological Monographs, v.67, p.345-366, 1997. DOI: 10.1890/0012-9615(1997)067[0345:SAAIST]2.0.CO;2.

FROUZ, J.; ROUBÍČKOVÁ, A.; HEDĚNEC, P.; TAJOVSKÝ, K. Do soil fauna really hasten litter decomposition? A meta-analysis of enclosure studies. European Journal of Soil Biology, v.68, p.18-24, 2015. DOI: 10.1016/j.ejsobi.2015.03.002.

GERLACH, J.; SAMWAYS, M.; PRYKE, J. Terrestrial invertebrates as bioindicators: an overview of available taxonomic groups. Journal of Insect Conservation, v.17, p.831-850, 2013. DOI: $10.1007 / \mathrm{s} 10841-013-9565-9$.

GIBSON, L.; LEE, T.M.; KOH, L.P.; BROOK, B.W.; GARDNER, T.A.; BARLOW, J.; PERES, C.A.; BRADSHAW, C.J.A.; LAURANCE, W.F.; LOVEJOY, T.E; SODHI, N.S. Primary forests are irreplaceable for sustaining tropical biodiversity. Nature, v.478, p.378-381, 2011. DOI: 10.1038/nature10425.
ISO. International Organization for Standardization. ISO 236115: Soil quality - Sampling of soil invertebrates - Part 5. Sampling and extraction of soil macro-invertebrates. [Geneva], 2011.

KAMAU, S.; BARRIOS, E.; KARANJA, N.K.; AYUKE, F.O.; LEHMANN, J. Soil macrofauna abundance under dominant tree species increases along a soil degradation gradient. Soil Biology and Biochemistry, v.112, p.35-46, 2017. DOI: 10.1016/j. soilbio.2017.04.016.

KORBOULEWSKY, N.; PEREZ, G.; CHAUVAT, M. How tree diversity affects soil fauna diversity: a review. Soil Biology and Biochemistry, v.94, p.94-106, 2016. DOI: 10.1016/j. soilbio.2015.11.024.

LAVELLE, P.; DOLÉDEC, S.; DE SARTRE, X.A.; DECAËNS, T.; GOND, V.; GRIMALDI, M.; OSZWALD, J.; HUBERT, B.; RAMIREZ, B.; VEIGA, I.; SOUZA, S. de; ASSIS, W.S de; MICHELOTTI, F.; MARTINS, M.; FEIJOO, A.; BOMMEL, P.; CASTAÑEDA, E.; CHACON, P.; VELASQUEZ, J.; DESJARDINS, T.; DUBS, F.; GORDILLO, E.; GUEVARA, E.; FONTE S., HURTADO, M. del P.; LENA, P.; LIMA, T.; MARICHAL, R.; MITJA, D.; MIRANDA. I.; OTERO, T.; PRAXEDES, C.; POCCARD, R.; ROBERT, P. de; RODRIGUEZ, G.; SANABRIA C.; TSELOUIKO, S.; VELASQUEZ, A.; VELASQUEZ, E.; VELASQUEZ, J. Unsustainable landscapes of deforested Amazonia: an analysis of the relationships among landscapes and the social, economic and environmental profiles of farms at different ages following deforestation. Global Environmental Change, v.40, p.137-155, 2016. DOI: 10.1016/j. gloenvcha.2016.04.009.

LAVELLE, P.; RODRÍGUEZ, N.; ARGUELLO, O.; BERNAL, J.; BOTERO, C.; CHAPARRO, P.; GÓMEZ, Y.; GUTIÉRREZ, A.; HURTADO, M. del P.; LOAIZA, S.; PULLIDO, S.X.; RODRÍGUEZ, E.; SANABRIA, C.; VELÁSQUEZ, E.; FONTE, S.J. Soil ecosystem services and land use in the rapidly changing Orinoco River Basin of Colombia. Agriculture, Ecosystems \& Environment, v.185, p.106-117, 2014. DOI: 10.1016/j. agee.2013.12.020.

LIMA, S.S. de; AQUINO, A.M. de; LEITE, L.F.C.; VELÁSQUEZ, E.; LAVELLE, P. Relação entre macrofauna edáfica e atributos químicos do solo em diferentes agroecossistemas. Pesquisa Agropecuária Brasileira, v.45, p.322-331, 2010. DOI: 10.1590/ S0100-204X2010000300013.

MARICHAL, R.; GRIMALDI, M.; FEIJOO, A.M; OSZWALD, J.; PRAXEDES, C.; RUIZ COBO, D.H.; HURTADO, M. del P.; DESJARDINS, T.; SILVA JUNIOR, M.L. da .; COSTA, L.G. da S.; MIRANDA, I.S.; OLIVEIRA, M.N.D.; BROWN, G.G.; TSÉLOUIKO, S.; MARTINS, M.B.; DECAËNS, T.; VELASQUEZ, E.; PATRICK, L. Soil macroinvertebrate communities and ecosystem services in deforested landscapes of Amazonia. Applied Soil Ecology, v.83, p.177-185, 2014. DOI: 10.1016/j.apsoil.2014.05.006.

MCGEOCH, M.A.; VAN RENSBURG, B.J.; BOTES, A. The verification and application of bioindicators: a case study of dung beetles in a savanna ecosystem. Journal of Applied Ecology, v.39, p.661-672, 2002. DOI: 10.1046/j.1365-2664.2002.00743.x.

MOÇO, M.K.S.; GAMA-RODRIGUES, E.F.; GAMARODRIGUES, A.C.; MACHADO, R.C.R.; BALIGAR, V.C. 
Relationships between invertebrate communities, litter quality and soil attributes under different cacao agroforestry systems in the south of Bahia, Brazil. Applied Soil Ecology, v.46, p.347-354, 2010. DOI: 10.1016/j.apsoil.2010.10.006.

MORALES-MÁRQUEZ, J.A.; HERNÁNDEZ-HERNÁNDEZ, R.M.; SÁNCHEZ, G.K.; LOZANO, Z.; CASTRO, I.; BRAVO, C.; RAMÍREZ, E.; JIMÉNEZ-BALLESTA, R. Soil macroinvertebrates community and its temporal variation in a well-drained savannah of the Venezuelan Llanos. European Journal of Soil Biology, v.84, p.19-26, 2018. DOI: 10.1016/j. ejsobi.2017.11.002.

NEGRETE-YANKELEVICH, S.; FRAGOSO, C.; NEWTON, A.C.; HEAL, O.W. Successional changes in soil, litter and macroinvertebrate parameters following selective logging in a Mexican Cloud Forest. Applied Soil Ecology, v.35, p.340-355, 2007. DOI: 10.1016/j.apsoil.2006.07.006.

OLIVEIRA, P.H.G.; GAMA-RODRIGUES, A.C.; GAMARODRIGUES, E.F.; SALES, M.V.S. Litter and soil-related variation in functional group abundances in cacao agroforests using structural equation modeling. Ecological Indicators, v.84, p.254-262, 2018. DOI: 10.1016/j.ecolind.2017.08.030.

PAULI, N.; BARRIOS, E.; CONACHER, A.J.; OBERTHÜR, T. Soil macrofauna in agricultural landscapes dominated by the Quesungual Slash-and-Mulch Agroforestry System, western Honduras. Applied Soil Ecology, v.47, p.119-132, 2011. DOI: 10.1016/j.apsoil.2010.11.005.

PEREIRA, J. de M.; SEGAT, J.C.; BARETTA, D.; VASCONCELLOS, R.L. de F.; BARETTA, C.R.D.M.; CARDOSO, E.J.B.N. Soil macrofauna as a soil quality indicator in native and replanted Araucaria angustifolia forests. Revista Brasileira de Ciência do Solo, v.41, e0160261, 2017. DOI: 10.1590/18069657rbcs20160261.

R CORE TEAM. R: A language and environment for statistical computing. Vienna: R Foundation for Statistical Computing, 2017. Available at: <http://r-project.org>. Accessed on: Aug. 272017.

ROSA, M.G. da; KLAUBERG FILHO, O.; BARTZ, M.L.C.; MAFRA, A.L.; SOUSA, J.P.F.A. de; BARETTA,
D. Macrofauna edáfica e atributos físicos e químicos em sistemas de uso do solo no Planalto catarinense. Revista Brasileira de Ciência do Solo, v.39, p.1544-1553, 2015. DOI: 10.1590/01000683rbcs20150033.

ROUSSEAU, L.; FONTE, S.J.; TÉLLEZ, O.; VAN DER HOEK, R.; LAVELLE, P. Soil macrofauna as indicators of soil quality and land use impacts in smallholder agroecosystems of western Nicaragua. Ecological Indicators, v.27, p.71-82, 2013. DOI: 10.1016/j.ecolind.2012.11.020.

SANTOS, D.P.; SANTOS, G.G.; SANTOS, I.L. dos; SCHOSSLER, T.R.; NIVA, C.C.; MARCHÃO, R.L. Caracterização da macrofauna edáfica em sistemas de produção de grãos no Sudoeste do Piauí. Pesquisa Agropecuária Brasileira, v.51, p.1466-1475, 2016. DOI: 10.1590/S0100-204X2016000900045.

SCORIZA, R.N.; SILVA, A. de P.; CORREIA, M.E.F.; LELES, P.S. dos S.; RESENDE, A.S. de. Efeito de herbicidas sobre a biota de invertebrados do solo em área de restauração florestal. Revista Brasileira de Ciência do Solo, v.39, p.1576-1584, 2015. DOI: 10.1590/01000683rbcs20150096.

SOCARRÁS, A. Mesofauna edáfica: indicador biológico de la calidad del suelo. Pastos y Forrajes, v.36, p.5-13, 2013.

VASCONCELLOS, R.L.F.; SEGAT, J.C.; BONFIM, J.A.; BARETTA, D.; CARDOSO, E.J.B.N. Soil macrofauna as an indicator of soil quality in an undisturbed riparian forest and recovering sites of different ages. European Journal of Soil Biology, v.58, p.105-112, 2013. DOI: 10.1016/j. ejsobi.2013.07.001.

VELÁSQUEZ, E.; FONTE, S.J.; BAROT, S.; GRIMALDI, M.; DESJARDINS, T.; LAVELLE, P. Soil macrofauna-mediated impacts of plant species composition on soil functioning in Amazonian pastures. Applied Soil Ecology, v.56, p.43-50, 2012. DOI: 10.1016/j.apsoil.2012.01.008.

WALL, D.H.; BARDGETT, R.D.; BEHAN-PELLETIER, V.; HERRICK, J.E.; JONES, T.H.; RITZ, K.; SIX, J. S TRONG, D.R.; VAN DER PUTTEN, W.H. (Ed.). Soil ecology and ecosystem services. Oxford: Oxford University Press, 2012. 405p. DOI: 10.1093/acprof:oso/9780199575923.001.0001.

$\overline{\text { Received on August 28, } 2017 \text { and accepted on March 1, } 2018}$

Pesq. agropec. bras., Brasília, v.53, n.12, p.1383-1391, Dec. 2018 DOI: $10.1590 / \mathrm{S} 0100-204 X 2018001200011$ 